\title{
Spatiotemporal Increases in Epidermal Growth Factor Receptors following Peripheral Nerve Injury
}

\author{
J. G. Toma, S. Pareek, P. Barker, ${ }^{a}$ T. C. Mathew, R. A. Murphy, A. Acheson, ${ }^{b}$ and F. D. Miller \\ Department of Anatomy and Cell Biology, University of Alberta, Edmonton, Canada T6G 2H7
}

Non-neuronal cells of peripheral nerve respond to axonal injury with a series of cellular changes that facilitate neuronal regeneration. To characterize the potential role of the epidermal growth factor (EGF) family of proteins in this response, we monitored the expression of EGF receptor mRNA and protein in the injured rat sciatic nerve. EGF receptor mRNA is synthesized in both primary cultured fibroblasts and Schwann cells, and Schwann cells express EGF receptor-like immunoreactivity. In s/tu hybridization and immunocytochemistry revealed that EGF receptor mRNA and protein are expressed in Schwann cells and fibroblasts of the sciatic nerve in vivo, and that receptor levels increase following nerve injury. Thirty-six hours postlesion, EGF receptors were expressed in gradients along the nerve both proximal and distal to the lesion, with the highest levels localized adjacent to the transection site. By $72 \mathrm{hr}$, receptor levels were maintained in a gradient in the proximal segment, but were uniformly increased throughout the portions of the distal segment that were analyzed. These changes were similar to those observed for low-affinity NGF receptor mRNA and protein, with transection causing increased expression in both Schwann cells and fibroblasts. Northern blots confirmed that primary cultured fibroblasts express low-affinity NGF receptor mRNA. To determine whether spatiotemporal gradients were a general characteristic of the nerve injury response, we monitored expression of the mRNA encoding the major myelin protein Po. Levels of Po mRNA decreased initially in cells immediately adjacent to the transection site and, by $72 \mathrm{hr}$, were uniformly decreased throughout the distal segment. These data suggest that members of the EGF family of proteins may play a role in the peripheral nerve response to injury, and demonstrate a generalized gradient of cellular responses that commence at the transection site

Received Oct. 2, 1991; revised Jan. 15, 1992; accepted Jan. 24, 1992.

We thank Yanling Ma, Julie Haskins, and Cheryl Richards for excellent technical assistance, and Robert Campenot, Richard Smith, and Warren Gallin for frequent discussions and advice. We also thank Ann Hubbard for the EGF receptor antibody, and Cary Lai for the rat EGF receptor cDNA clone prior to publication. This work was supported by the Canadian Network of Excellence for Neural Regeneration and Functional Recovery, and by grants from the Canadian M.R.C. and the Alberta Heritage Foundation for Medical Research (A.H.F.M.R.) to F.D.M., R.A.M., and A.A. J.G.T. is supported by a fellowship from the Rick Hansen Foundation for Spinal Cord Research, P.B. by a studentship from the A.H.F.M.R., and T.C.M. by a studentship from the Alberta Association for Paraplegic Research; F.D.M. and A.A. are A.H.F.M.R. Scholars.

Correspondence should be addressed to Dr. Freda D. Miller, Department of Anatomy and Cell Biology, 5-14 Medical Sciences Building, University of Alberta, Edmonton, Alberta, Canada T6G $2 \mathrm{H} 7$.

a Present address: Department of Neuroscience, Stanford University, Palo Alto, CA 94025.

b Present address: Regeneron Pharmacenticals, 777 Old Saw Mill River Road, Tarrytown, NY 10591.

Copyright (C) 1992 Society for Neuroscience $0270-6474 / 92 / 122504-12 \$ 05.00 / 0$ and progress distally in the nerve in the absence of intact axons.

Following nerve injury, functional axonal regeneration can occur in the PNS (Ramon y Cajal, 1928; Guth, 1956) but not the CNS (Ramon y Cajal, 1928; Guth, 1975; Veraa and Grafstein, 1981). However, when provided with a PNS environment, CNS neurons can elongate lesioned processes (Ramon y Cajal, 1928; Richardson et al., 1980; David and Aguayo, 1981; Benfey and Aguayo, 1982). Conversely, grafted segments of CNS nerve prevent the regeneration of PNS axons (Anderson and Turmaine, 1986; Anderson et al., 1989). These studies support the concept that axonal regeneration does not depend upon the location of the cell body, but rather is a function of the environment that surrounds the severed axon.

The cellular environment of the injured distal nerve segment is important for successful peripheral nerve regrowth (Politis et al., 1982; Scaraville, 1984; Williams et al., 1984). Following nerve injury, the distal segment undergoes a process known as Wallerian degeneration, which involves axonal fragmentation, debris removal, and proliferation of Schwann cells and other non-neuronal cells (reviewed in Allt, 1976). Macrophages, which invade the injured nerve (Perry et al., 1987), phagocytose and degrade axons and myelin membrane, and stimulate the proliferation of Schwann cells (Beuche and Friede, 1984; Baichwal et al., 1988; Stoll et al., 1989). Thus, the environment through which axons regenerate in the PNS consists of Schwann cells and their associated basal lamina, fibroblasts, and collagen and, at early stages, axonal debris, degenerating myelin, and phagocytic cells.

Non-neuronal cells in peripheral nerves must provide a supportive, noninhibitory environment for successful axonal regeneration to occur. Therefore, they need to facilitate local wound healing, and provide trophic support and a permissive substrate for injured neurons. Schwann cells fulfill the latter two functions by providing a suitable substrate for axonal growth (Schwab and Thoenen, 1985; Carbonetto et al., 1987; Savio and Schwab, 1989) and by synthesizing trophic factors including NGF (Heumann et al., 1987a) and brain-derived neurotrophic factor (BDNF) (Acheson et al., 1991). Peripheral nerve fibroblasts also contribute to the wound healing response (Adelmann-Grill et al., 1990; Finesmith et al., 1990), since they too secrete NGF and BDNF-like activities into conditioned media (Acheson et al., 1991) and increase expression of NGF mRNA when exposed to interleukin-1, which is produced by macrophages that invade the site of injury (Lindholm et al., 1988).

Schwann cells dramatically alter their phenotype in response to nerve injury. The low-affinity NGF receptor (LNGF receptor), which is expressed at low levels in the adult nerve, is 
strongly induced by axotomy (Taniuchi et al., 1986, 1988; Heumann et al., 1987a,b; Raivich and Kreutzberg, 1987). In contrast, synthesis of the major myelin protein Po declines after nerve injury (Gupta et al., 1988; Trapp et al., 1988; LeBlanc and Poduslo, 1990). It has been hypothesized that these changes are a consequence of disruption of Schwann cell-axon contact (Taniuchi et al., 1988; Brunden et al., 1990; LeBlanc and Poduslo, 1990).

The epidermal growth factor (EGF) receptor is a transmembrane protein related to the V-erb-B proto-oncogene that contains a glycosylated ligand-binding domain, a transmembrane region, and a cytoplasmic tyrosine kinase domain (Downward et al., 1984). Binding to the receptor of either EGF or transforming growth factor- $\alpha$ (TGF- $\alpha$ ), members of the EGF family of proteins, leads to receptor dimerization and activation of tyrosine kinase activity, resulting ultimately in cell division (reviewed in Carpenter, 1987; Ullrich and Schlessinger, 1990). Although the role of the EGF receptor in the PNS is unknown, EGF treatment of CNS non-neuronal cells increases DNA synthesis (Leutz and Schachner, 1981; Huff et al., 1990).

In this study, we demonstrate that EGF receptors increase in both Schwann cells and fibroblasts of rat sciatic nerve following injury. In situ hybridization and immunocytochemistry demonstrate that, immediately following axotomy, EGF receptor mRNA and protein increase in longitudinal gradients in both the proximal and distal nerve segments, with the highest levcls occurring at the site of injury. By $72 \mathrm{hr}$ postaxotomy, EGF receptors are uniformly increased throughout the length of the distal segment. This pattern of increased EGF receptor production is very similar to that observed for LNGF receptors, suggesting that spatial/temporal gradients, which are coincident with Wallerian degeneration, may be a generalized response to peripheral nerve injury. Further support for this idea arises from our studies demonstrating that Schwann cell expression of the mRNA encoding the major myelin protein Po also decreases in a gradient fashion. Taken together, these data implicate members of the EGF family in the nerve injury response, and suggest that injury-induced changes in non-neuronal cells of peripheral nerves occur as a function of distance from the lesion site, perhaps due to the absence of intact axons.

\section{Materials and Methods}

Animals and surgical procedures. Female Sprague-Dawley rats (150$200 \mathrm{gm}$ ) were anesthetized with sodium pentobarbital $(35 \mathrm{mg} / \mathrm{kg})$, and the sciatic nerve was unilaterally transected at mid-thigh level. At various times following axotomy, animals were again anesthetized and transcardially perfused with $4 \%$ paraformaldehyde. The intact (control) and transected sciatic nerves were removed, fixed overnight in $4 \%$ paraformaldehyde in phosphate buffer at $\mathrm{pH} 7.4$, and cryoprotected in graded sucrose solutions. Longitudinal cryostat sections $(10 \mu \mathrm{m})$ were mounted on chrom-alum subbed slides, taking care to include the cap of the transected segment and at least $1 \mathrm{~cm}$ of the nerve. Alternatively, some nerves were processed as cross sections. At least four different animals were analyzed for each time point.

Tissue culture. Schwann ccll culturcs wcre cstablishcd as describcd (Brockes et al., 1979; Barker et al., 1991), and maintained on poly-Llysine-coated tissue culture flasks in Dulbecco's modified Eagle's medium (DMEM) containing 10\% fetal calf serum, $10 \mu \mathrm{g} / \mathrm{ml}$ crude glial growth factor (Gospodarowicz, 1975), and $5 \mu \mathrm{g} / \mathrm{ml}$ forskolin. Primary dermal fibroblasts were established as previously described (Acheson et al., 1991) and maintained in DMEM containing $10 \%$ fetal calf serum. Experiments involving primary cells were performed on cells between passages 5 and 10 . An immortal line of sciatic nerve fibroblasts grew from a mixed population of Schwann cells and fibroblasts cultured from the sciatic nerve of rat pups $60-72 \mathrm{hr}$ old. These cells were maintained in HEPES-buffered DMEM supplemented with $10 \%$ fetal calf serum and gentamycin. The sciatic nerve fibroblast lines retained their fibroblast-like morphology and expressed very low levels of S100 protein, confirming that they were not Schwann cells.

Hybridization probes. Antisense RNA probes specific to EGF receptor were generated from a fragment containing nucleotides 2058-2754 of the human cDNA (Ullrich et al., 1984) subcloned into pGEM 3Z. This subclone was linearized with BamHI, and transcribed with SP6 RNA polymerase to generate an antisense RNA probe homologous to nucleotides 2613-2754, which corresponds to amino acids 871-918 of the intracellular tyrosine kinase domain. Under our hybridization conditions, this probc is spccific for EGF rcceptor mRNA. Altcrnativcly, antisense RNA probes were generated from a subcloned cDNA fragment containing the tyrosine kinase domain of the rat EGF receptor (Lai and Lemke, 1991) (kindly donated by Dr. Cary Lai, Salk Institute). Antisense RNA probes specific to $L N G F$ receptor were generated from a 310 nucleotide EcoRI/BamHI fragment containing nucleotides 400-710 of the rat cDNA (Radeke et al., 1987) (kindly donated by Dr. Moses Chao, Cornell University Medical School), as previously described (Miller et al., 1991). Antisense RNA probes specific to mRNAs encoding somatostatin (Goodman et al., 1983) and tyrosine hydroxylase (Lewis et al., 1983) were generated as previously described (Naus et al., 1988; Miller et al., 1991). Antisense RNA probes for Po mRNA (Lemke and Axel, 1985) were generated from a subclone kindly provided by Dr. Greg Lemke (Salk Institute).

Antibodies. Polyclonal anti-EGF receptor $\mathrm{IgG}$ was kindly provided by Dr. Ann Hubbard (Johns Hopkins University) and used at a concentration of $1 \mu \mathrm{g} / \mathrm{ml}$ for immunostaining. This antiserum specifically recognized both the mature and truncated forms of EGF receptor on immunoblots of extracts of A431 cells and rat liver (A. Hubbard, personal communication). $192 \mathrm{IgG}$ is a mouse monoclonal antibody first described by Chandler et al. (1984). The binding site of $192 \mathrm{IgG}$ is present within the extracellular domain of the NGF receptor. 192 IgGproducing hybridomas were used to produce ascites fluid in mice, and IgG was isolated using the Pierce Immunopure method according to the manufacturer's instructions. This antibody was used for immunostaining at a final concentration of $3 \mu \mathrm{g} / \mathrm{ml}$. Purified rabbit anti-cow S100 IgG was obtained from Dakopatts (Glostrup, Denmark) and used at a concentration of $10.8 \mu \mathrm{g} / \mathrm{ml}$ for immunostaining.

RNA isolations and Northern blots. RNA isolations were performed on cultured cells using the guanidine hydrochloride method. PolyA+enriched RNA was selected by passage over oligo(dT) cellulose (Collaborative Research). RNA was separated by electrophoresis, transferred to nitrocellulose or Nytran (Schleicher and Schuell), and hybridized to ${ }^{32} \mathrm{P}$-labeled antisense RNA probes as previously described (Miller et al., 1991).

Immunocytochemistry. Slide-mounted nerve sections were fixed by a brief $5 \mathrm{~min}$ exposure to $4 \%$ paraformaldehyde in phosphate buffer, $\mathrm{pH}$ 7.4. The sections were permeabilized with HEPES-buffered saline (HBS; $10 \mathrm{~mm}$ HEPES, pH 7.4, $150 \mathrm{~mm} \mathrm{NaCl}$ ) containing $0.1 \%$ Triton X-100 for $5 \mathrm{~min}$. The Triton was removed with two HBS washes. Nonspecific binding was blocked by a $30 \mathrm{~min}$ incubation in HBS containing $2 \%$ fetal calf serum and $2 \%$ rat serum (HBS/FCS/RS). Sections were incubated with appropriate concentrations of the primary antibody diluted in $\mathrm{HBS} / \mathrm{FCS} / \mathrm{RS}$ overnight at $4^{\circ} \mathrm{C}$. Following two washes with $\mathrm{HBS}$, sections were incubated with a biotinylated secondary antibody (donkey anti-rabbit IgG or rat anti-mouse IgG; Jackson Immunoresearch) diluted to a final concentration of $1 \mu \mathrm{g} / \mathrm{ml}$ in either HBS/RS containing $2 \%$ donkey serum or simply HBS/RS, as appropriate. Finally, the sections were incubated with Texas red-streptavidin (Amersham; $4 \mu \mathrm{l} / \mathrm{ml}$ in HBS) for $1 \mathrm{hr}$ at room temperature, washed three times (at least 5 min each wash) with HBS, and mounted in Mowiol (Osborn and Weber, 1982). For cultured cells, the same immunostaining procedure was used, except that cells were fixed for $20 \mathrm{~min}$ in $4 \%$ paraformaldehyde prior to pcrmcabilization.

Controls and immunostaining. We initially found a high degree of nonspecific binding, especially in longitudinal sections of the distal stump of cut nerve. To minimize nonspecific binding, it was necessary to (1) include $2 \%$ rat serum in all of the antibody solutions, (2) use secondary antibodies that had been preabsorbed to minimize cross-reactivity with rat serum proteins, and (3) use nonspecific IgG as a control for all immunostaining experiments. As a control for $192 \mathrm{IgG}$ staining, we used IgG from a nonspecific mineral oil plasmacytoma $\left(\mathrm{MOPC}_{21}\right.$, obtained from Organon Teknika) at $3 \mu \mathrm{g} / \mathrm{ml}$. As controls for EGF receptor and S100 staining, we used preimmune rabbit IgG $(10 \mu \mathrm{g} / \mathrm{ml})$. Addi- 

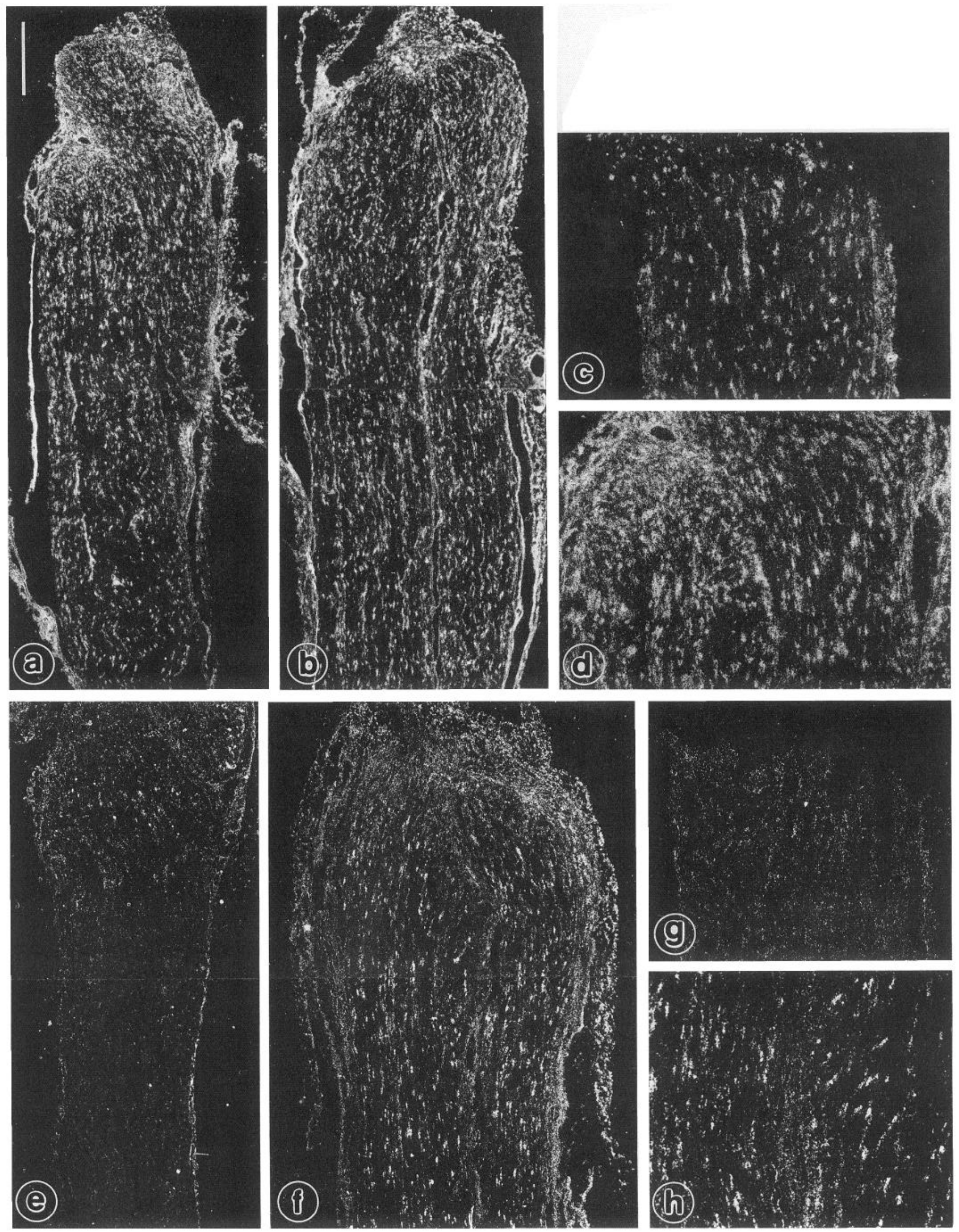


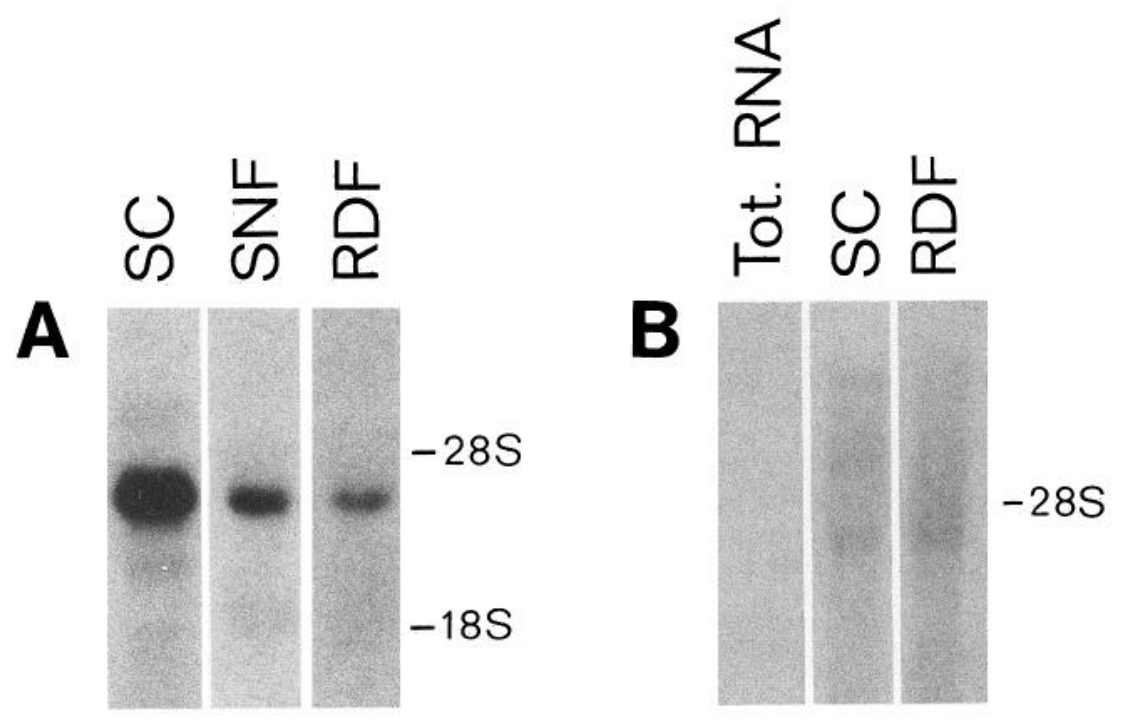

Figure 2. Northern blot analysis for LNGF receptor $(A)$ and EGF receptor $(B)$ mRNAs in Schwann cells and fibroblasts. $A$, Total RNA isolated from Schwann cells $(S C)$, dermal fibroblasts $(R D F)$, and sciatic nerve fibroblasts $(S N F)$ was hybridized to a probe specific for LNGF receptor mRNA. The relative intensities of the autoradiographs do not accurately reflect the relative levels of LNGF receptor mRNA in these different cell types, since all of the lanes come from different Northern blots that have been exposed for different lengths of time. The migration of the $28 \mathrm{~S}$ and $18 \mathrm{~S}$ ribosomal RNAs is indicated by the bars to the right of the panel. B, Equal amounts of poly $\mathrm{A}^{+}$RNA isolated from Schwann cells $(S C)$ and dermal fibroblasts $(R D F)$ were hybridized to a probe specific for the tyrosine kinase domain of the rat EGF receptor. Lack of hybridization to a similar amount of total RNA (Tot. RNA) indicates the specificity of the signal. The migration of the 28S ribosomal RNA is indicated by the bar to the right of the panel.

tional controls, including elimination of primary or secondary antibody, yielded little detectable staining. Nonetheless, a small amount of nonspecific immunostaining was detected routinely at the cap region of the cut sciatic nerve and associated with the collagenous portion of the nerve sheath located outside of the perineurium.

In situ hybridization. In situ hybridization was performed with antisense probes as previously described (Miller et al., 1989a). After hybridization, slides were air dried and apposed to Kodak XRP film for $1-5 \mathrm{~d}$ to obtain $\mathrm{x}$-ray images. The slides were subsequently dipped in Kodak NTB-2 emulsion and exposed for 2-7 d prior to development. Hybridization with sense probes, as well as heterologous probes specific for mRNAs not present in the sciatic nerve (tyrosine hydroxylase and somatostatin), was performed to ensure specificity of hybridization. Alternate tissue sections were stained with hematoxylin and eosin to facilitate the identification of specific cell types.

Analysis and quantitation. To minimize variability, we mounted and processed control and lesioned nerves on the same slides (Miller et al., $1989 \mathrm{a}, \mathrm{b})$ and photographed and printed sections using identical exposure times.

\section{Results}

\section{Increased expression of EGF receptors in the transected} sciatic nerve

To determine whether EGF receptor mRNA is expressed in the sciatic nerve, we performed in situ hybridization on longitudinal sections of control, uninjured nerve. EGF receptor mRNA is expressed at detectable levels in cells throughout the endoneurium, presumably Schwann cells, and in cells of the epineurium, presumably fibroblasts (Fig. 1c). To confirm these results, we isolated polyA ${ }^{+}$RNA from Schwann cells cultured from the sciatic nerve and from primary fibroblasts cultured from the dermis. Northern blot analyses demonstrated that EGF receptor mRNA is expressed in both cell types, at approximately equal levels (Fig. $2 B$ ). Transcripts of approximately 9.5, 6.5, and 5.0 kilobases were detected (Fig. $2 B$ ). Immunostaining with an EGF receptor-specific polyclonal antibody confirmed the presence of EGF receptor protein on cultured Schwann cells, although the cells did not all stain homogeneously (Fig. $3 a, b$ ). Levels of EGF receptor were also much lower than on A431 cells (Fig. $3 c, d$ ), which express approximately $3 \times 10^{6} \mathrm{EGF}$ binding sites per cell (Haigler et al., 1978).

To determine whether EGF receptor mRNA levels were altered by nerve injury, we performed in situ hybridization on longitudinal sections of sciatic nerve transected for 3,36 , or 72 hr. Three hours postaxotomy, sections of cut nerve appeared similar to intact controls. By $36 \mathrm{hr}$ posttransection, however, EGF receptor mRNA was increased in cells located adjacent to the cut site, and, to a lesser degree, throughout the epineurium of the distal segment (data not shown). Levels of EGF receptor mRNA continued to increase until, by $72 \mathrm{hr}$ posttransection, the distal nerve segment uniformly expressed elevated levels of EGF receptor mRNA. Increased hybridization was evident both in Schwann cells in the endoneurium, and in cells located in the epineurium (Fig. 1b). A similar increase in EGF receptor mRNA was observed in the proximal stump, with levels highest near

Figure 1. Expression of EGF receptor $(a-d)$ and LNGF receptor $(e-h)$ mRNAs in the sciatic nerve 72 hr postaxotomy, as detected by in situ hybridization followed by emulsion autoradiography. Longitudinal sections of the proximal $(a)$ and distal $(b)$ segments of transected sciatic nerve were hybridized to probes specific for EGF receptor mRNA, processed for emulsion autoradiography, and visualized using dark-field illumination. Alternate sections of the proximal $(e)$ and distal $(f)$ segments were hybridized to probes specific for LNGF receptor mRNA. In $c$ and $d$, the increase in EGF receptor mRNA in the transected proximal segment $(d)$ relative to the control nerve $(c)$ is shown at higher magnification. Similarly, in $g$ and $h$ the increased LNGF receptor mRNA in the transected distal segment $(h)$ relative to the control nerve $(g)$ is shown at higher magnification. In $a, b, e$, and $f$, the transected tip is located at the top of the photograph. Scale bar: $500 \mu \mathrm{m}$ for $a, b, e$, and $f ; 250 \mu \mathrm{m}$ for $c, d, g$, and $h$. 

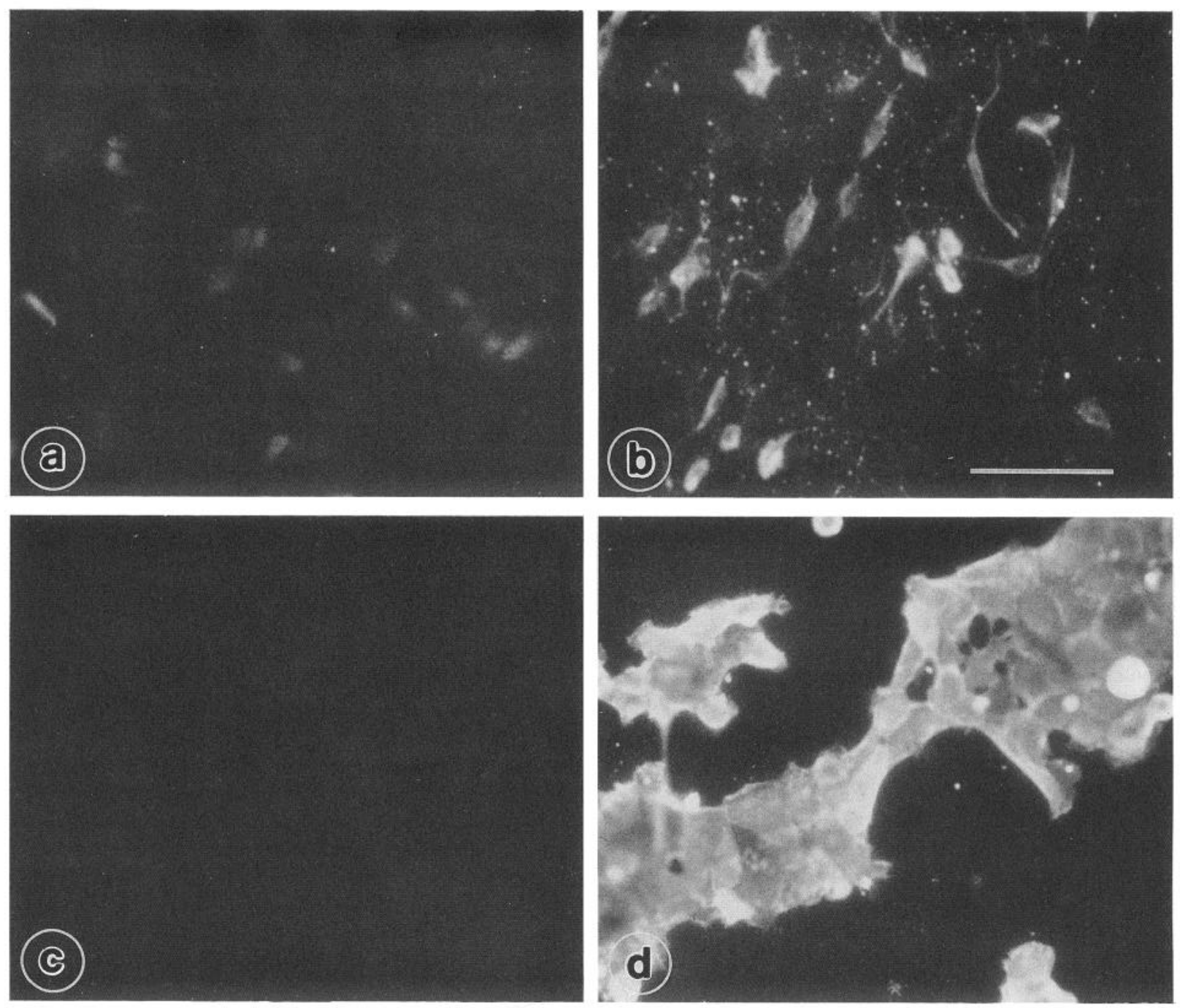

Figure 3. Immunocytochemical detection of EGF receptors in rat Schwann cells $(b)$ and A431 human epidermoid carcinoma cells $(d)$. $a$ represents Schwann cells stained with a nonimmune rabbit $\mathrm{IgG}$, and photographed and printed under identical conditions to $b . c$ represents A431 cells stained with nonimmune rabbit IgG, and photographed and printed under identical conditions to $d$. Note that the Schwann cells for this experiment were cultured at low density. Scale bar, $100 \mu \mathrm{m}$.

the transection site and decreasing along a gradient to reach control levels within approximately $3-4 \mathrm{~mm}$ from the cut side (Fig. 1 $a, c, d)$. Hybridization of adjacent sections with sense probes or heterologous probes resulted only in a low background signal.

To confirm that increased levels of EGF receptor mRNA coincided with a similar increase in EGF receptor protein, we performed immunocytochemistry on adjacent, transected nerve sections (Fig. 4). At all time points, the results were identical. Three hours postaxotomy, EGF receptor-like immunoreactivity was similar in sections of control and transected nerve. By 36 $\mathrm{hr}$, staining was slightly increased close to the transection site, and in the distal nerve segment (data not shown). By $72 \mathrm{hr}$ posttransection, immunostaining was uniformly increased throughout the distal nerve segment, in the body of the nerve, and in the connective tissue (Fig. 4d). Similar increases were evident in the proximal nerve stump close to the transection site, but decreased to control levels approximately $3-4 \mathrm{~mm}$ from the tip (Fig. $4 a-c$ ).

To determine whether the increase in EGF receptor immunoreactivity was specific, we stained adjacent longitudinal sec- tions with an antibody to the $\mathrm{S} 100 \beta$ protein (Fig. $4 g, h$ ), or to nonspecific control antibodies (Figs. $4 f, 5 e$ ). In control nerve, S100-like immunoreactivity was located throughout the body of the nerve, consistent with previous observations (Kligman and Hilt, 1988). Seventy-two hours following transection, staining was similar to controls (Fig. $4 g, h$ ). Staining of adjacent sections with a polyclonal nonimmune rabbit IgG, or with IgG isolated from a nonspecific plasmacytoma cell line, gave only low levels of background immunofluorescence (Figs. 4f, $5 e$ ).

\section{Expression of $L N G F$ receptors in Schwann cell and fibroblasts of the injured nerve}

Levels of LNGF receptor increase following peripheral nerve injury, as demonstrated by Northern blot analysis (Heumann et al., 1987b) and immunocytochemistry (Taniuchi et al., 1986). To compare the time course and pattern of changes for EGF receptor to those for LNGF receptor, we performed in situ hybridization on adjacent longitudinal nerve sections. This analysis confirmed that LNGF receptor mRNA was expressed at low, but detectable, levels in Schwann cells throughout the body 

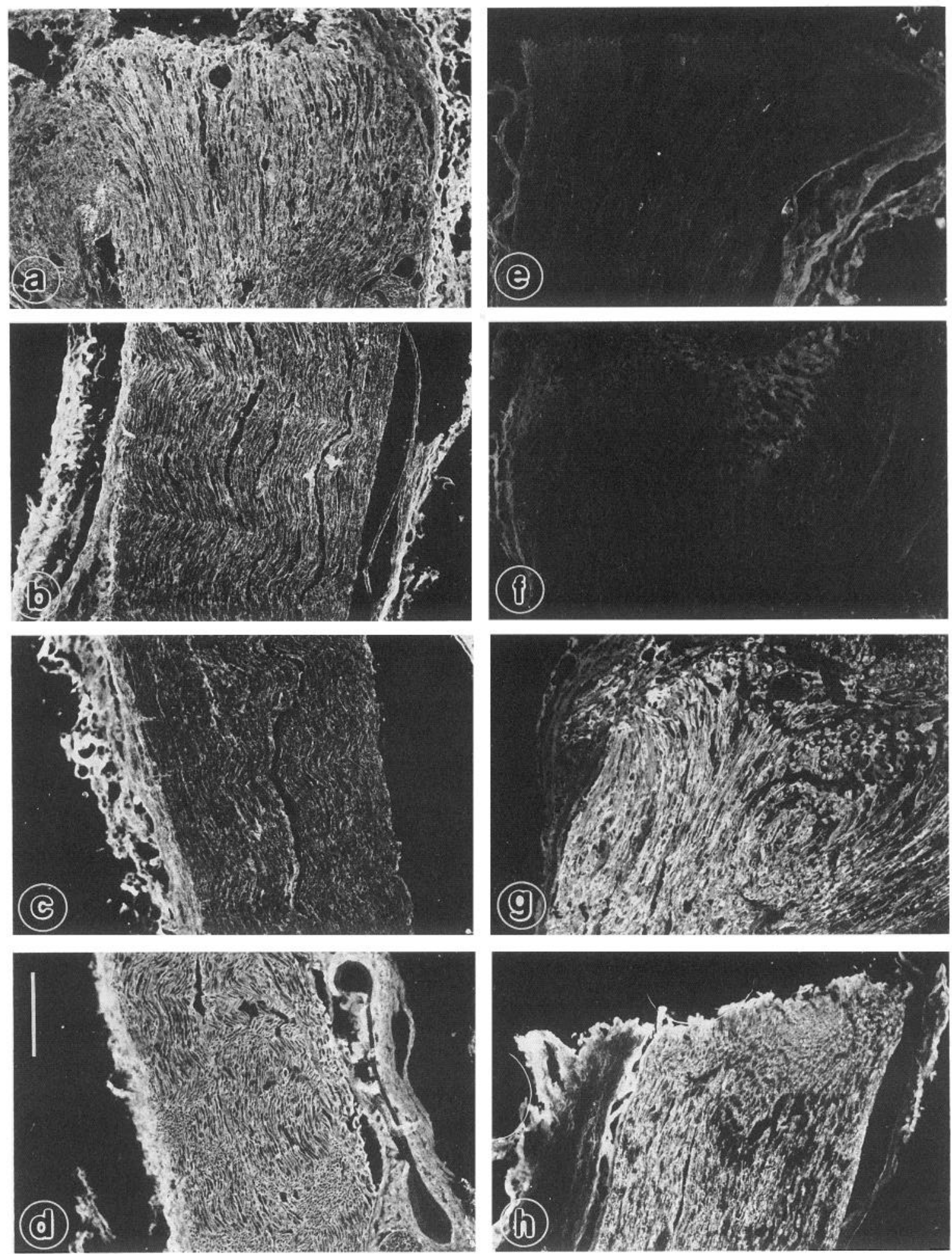

Figure 4. Immunocytochemical detection of EGF receptor $(a-e)$ and $\mathrm{S} 100 \beta$ protein $(g, h)$ in the control and transected sciatic nerve 72 hr postaxotomy. The gradient of EGF receptor immunoreactivity in the proximal sciatic nerve is demonstrated in $a-c$, where $a$ is the proximal tip of transected nerve, $b$ is $2-3 \mathrm{~mm}$ from the tip, and $c$ is $4-5 \mathrm{~mm}$ from the tip. All photographs are taken from the same section. EGF receptor immunoreactivity is also increased in the distal segment $(d)$ relative to the control, uncut nerve $(e)$. In $a-c$ and $e$, all photographs originate from the same slide, and were exposed and printed under identical conditions. Alternate sections of the proximal, transected segment $(g)$ and the control, uncut nerve $(h)$ were also stained with an antibody specific to the $S 100 \mathrm{~b}$ protein, which does not change as a function of axotomy. $f$ is a longitudinal section of the proximal stump stained with nonimmune rabbit IgG. In $a$ and $e-h$, the transected tip is oriented at the top of the photograph. Scale bar, $500 \mu \mathrm{m}$. 

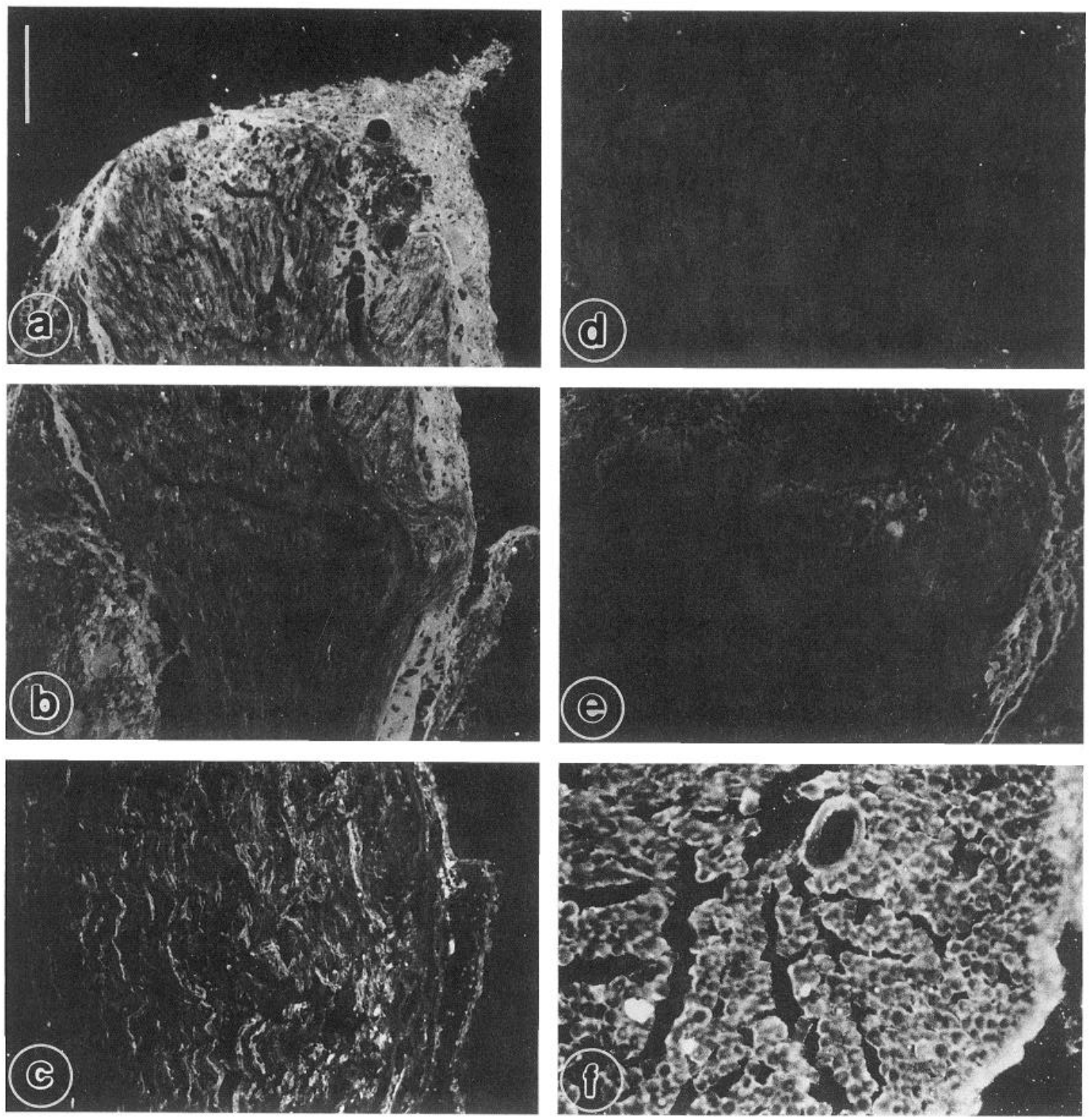

Figure 5. Immunocytochemical detection of LNGF receptor in the control and transected sciatic nerve $72 \mathrm{hr}$ postaxotomy. The gradient of 192 IgG immunoreactivity in the proximal segment is demonstrated in $a$ and $b$, where $a$ is the proximal tip and $b$ is $2-3 \mathrm{~mm}$ from the tip. 192 IgG immunoreactivity is also increased in the distal segment $(c)$ relative to the control, uncut nerve $(d)$. The staining of the epineurium following transection is particularly obvious in cross sections of the distal sciatic nerve $(f)$, here at $36 \mathrm{hr}$ postaxotomy. $e$ is a longitudinal section of the proximal segment $72 \mathrm{hr}$ postaxotomy stained with $\mathrm{IgG}$ isolated from the murine plasmacytoma $\mathrm{MOPC}_{21}$. All photographs in $a-e$ were exposed and printed under identical conditions, while $f$ was not. Scale bar, $500 \mu \mathrm{m}$.

of the nerve (Fig. $1 \mathrm{~g}$ ). Thirty-six hours posttransection, LNGF receptor mRNA was elevated in gradients in both the proximal and distal segments of the nerve, with the highest receptor mRNA levels adjacent to the lesion site, and lower levels distally (data not shown). Seventy-two hours postaxotomy, LNGF receptor mRNA was expressed in a gradient in the proximal segment (Fig. 1e) but was uniformly elevated throughout the distal segment (Fig. $1 f-h$ ).

In addition to LNGF receptor mRNA being increased in Schwann cells, as previously reported (Taniuchi et al., 1986), high levels of signal were also detected in the epineurium, presumably within fibroblasts (Fig. 1f). To confirm this novel localization for LNGF receptor mRNA, we cultured fibroblasts from the dermis or from the sciatic nerve. Northern blots dem- onstrated that both of these types of fibroblasts express LNGF receptor mRNA (Fig. $2 A$ ), which ribonuclease protection assays show is identical to LNGF receptor mRNA expressed in Schwann cells (data not shown; Barker, 1991). However, levels of LNGF receptor mRNA were much lower in cultured fibroblasts than in cultured Schwann cells (data not shown; Barker, 1991).

To confirm that the increase in LNGF receptor mRNA in the epineurium is associated with a corresponding increase in levels of the protein, we stained adjacent longitudinal nerve sections with the monoclonal antibody $192 \mathrm{IgG}$. By $72 \mathrm{hr}$ posttransection, staining for LNGF receptor was elevated in both the endoneurium and the epineurium of the distal nerve segment (Fig. $5 c, d$ ). Staining was similarly increased in the proximal stump near the site of injury, and decreased to control levels $2 \mathrm{~mm}$ 

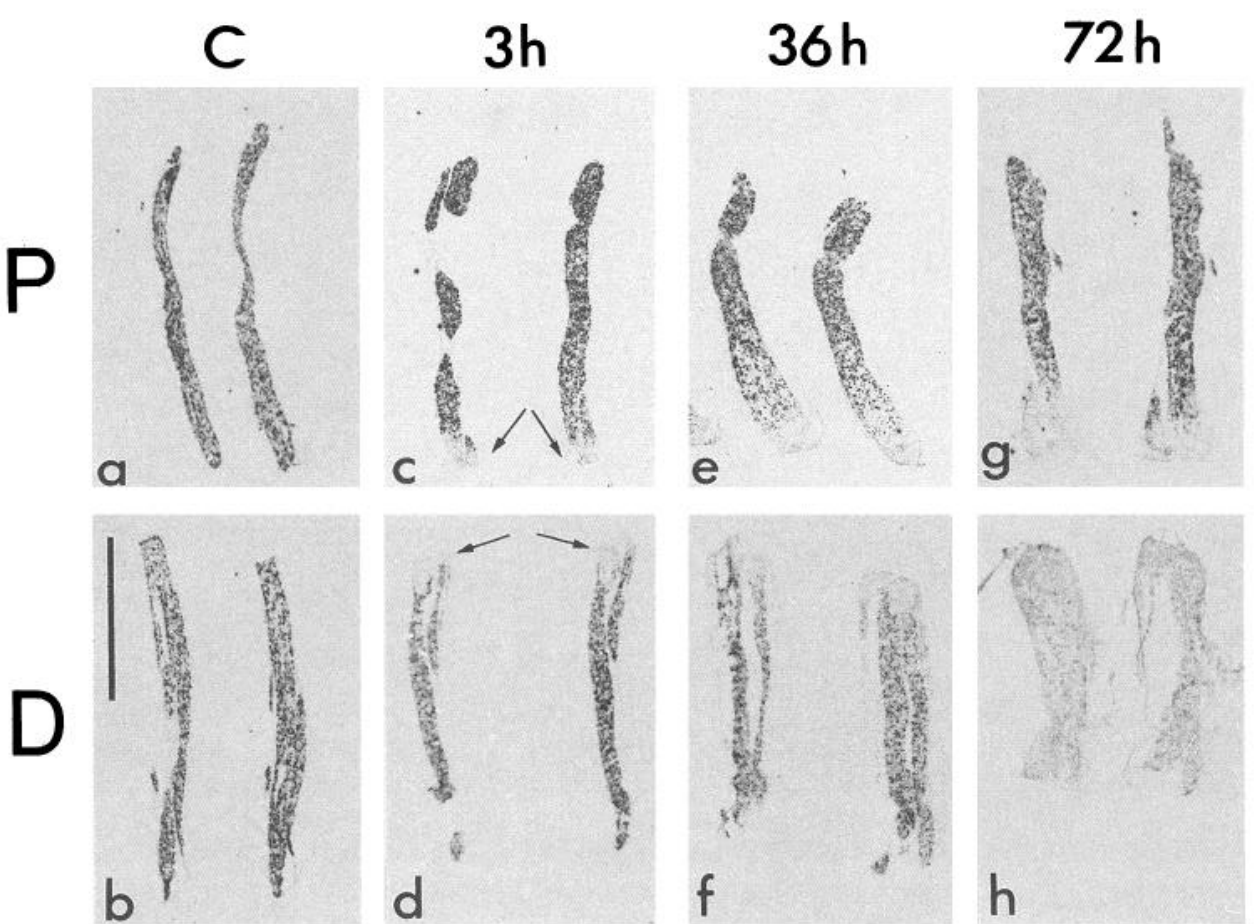

Figure 6. Expression of Po mRNA in the control and transected sciatic nerve at 3,36 , and $72 \mathrm{hr}$ postaxotomy, as detected by in situ hybridization. Longitudinal sections of control $(a, b)$ and transected $(c-h)$ sciatic nerve were hybridized to a probe specific for Po mRNA, and apposed to $x$-ray film. Sections of both the proximal $(P)(c, e, g)$ and distal $(D)(d, f, h)$ segments are shown at $3 \mathrm{hr}(c, d), 36 \mathrm{hr}(e, f)$, and $72 \mathrm{hr}(g, h)$ postaxotomy. Arrows indicate the transection site, which is at the bottom of the sections shown in $a$, $c, e$, and $g$ and the top of those shown in $b, d, f$, and $h$. Scale bar, $5 \mathrm{~mm}$. from the cut site (Fig. $5 a, b$ ). Staining of nerve cross sections confirmed that LNGF receptor-like immunoreactivity was increased in both the body of the nerve and the epineurium (Fig. $5 f)$.

\section{Spatiotemporal gradients in expression of Po $m R N A$ following nerve injury}

To determine whether the observed gradients in expression of EGF and LNGF receptors were a general characteristic of the nerve injury response, we examined changes in expression of the mRNA encoding the peripheral myelin protein Po, which has been shown to decrease in Schwann cells $2 \mathrm{~d}$ postaxotomy (Gupta et al., 1988; Trapp et al., 1988). Longitudinal sections of sciatic nerve transected for 3,36 , and $72 \mathrm{hr}$ were hybridized to a probe specific for Po mRNA. In control animals, Po mRNA was expressed at approximately the same level in Schwann cells throughout the length of the sciatic nerve (Figs. $6 a, b ; 7 e$ ). Levels of Po mRNA decreased, however, in Schwann cells located close to the transection site as early as $3 \mathrm{hr}$ postaxotomy (Figs. $6 c, d$; $7 a$ ). By $36 \mathrm{hr}$ posttransection, Schwann cells close to the transection site expressed little detectable Po mRNA, with increased levels of expression evident approximately $3-4 \mathrm{~mm}$ down the nerve (Figs. $6 e, f ; 7 b-e$ ). By $72 \mathrm{hr}$ posttransection, Po mRNA expression was uniformly reduced in Schwann cells throughout the distal segment, whereas the decrease in the proximal segment was limited to the region immediately adjacent to the transection site (Fig. $6 g, h$ ). Thus, at early time points following transection (3-72 hr), Schwann cells of the injured nerve respond in spatiotemporal gradients that commence at the transection site.

\section{Discussion}

The present experiments indicate that (1) EGF receptors are expressed in Schwann cells, (2) surgical transection of rat sciatic nerve upregulates EGF receptors in both Schwann cells and nerve fibroblasts, and (3) this increase occurs in a graded fashion with elevated levels occurring first at the transection site, and spreading distally at later time points. The temporal and spatial regulation of the EGF receptor as a function of nerve injury is strikingly similar to that seen for LNGF receptors, which increase not only in Schwann cells, as previously reported (Taniuchi et al., 1986), but also in cells of the connective tissue, presumably fibroblasts. Furthermore, the mRNA encoding the major myelin protein Po decreases in a gradient progressing from the injured tip throughout the distal segment, supporting the generality of the observed spatiotemporal gradients. These data therefore suggest an important role for members of the EGF family in the nerve injury response, and demonstrate a generalized gradient of cellular responses in the injured nerve.

Within the intact sciatic nerve, EGF receptor mRNA and protein were detected in cells of the epineurial and perineurial sheaths as well as within the body of the nerve, suggesting that both fibroblasts and Schwann cells express this receptor. This conclusion is supported by our data demonstrating that both cell types express EGF receptor mRNA transcripts of a size similar to that previously reported in rat cell lines and tissues (Earp et al., 1986), and that Schwann cells express EGF receptorlike immunoreactivity. Following nerve transection, EGF receptors first increased in longitudinal gradients in both the proximal and distal segments, while by $72 \mathrm{hr}$ they were elevated throughout the entire portion of the distal segment that we examined. At both of these time points, EGF receptor mRNA and protein were increased in cells of the connective tissue matrix as well as in Schwann cells.

The factors responsible for increased EGF receptor expression are unknown. The number and/or affinity of EGF receptors on fibroblasts can be modulated by platelet-derived growth factor (Bowen-Pope et al., 1983; Collins et al., 1983) and TGF- $\beta$ (Assoian et al., 1984; Massague, 1985), both of which are produced 

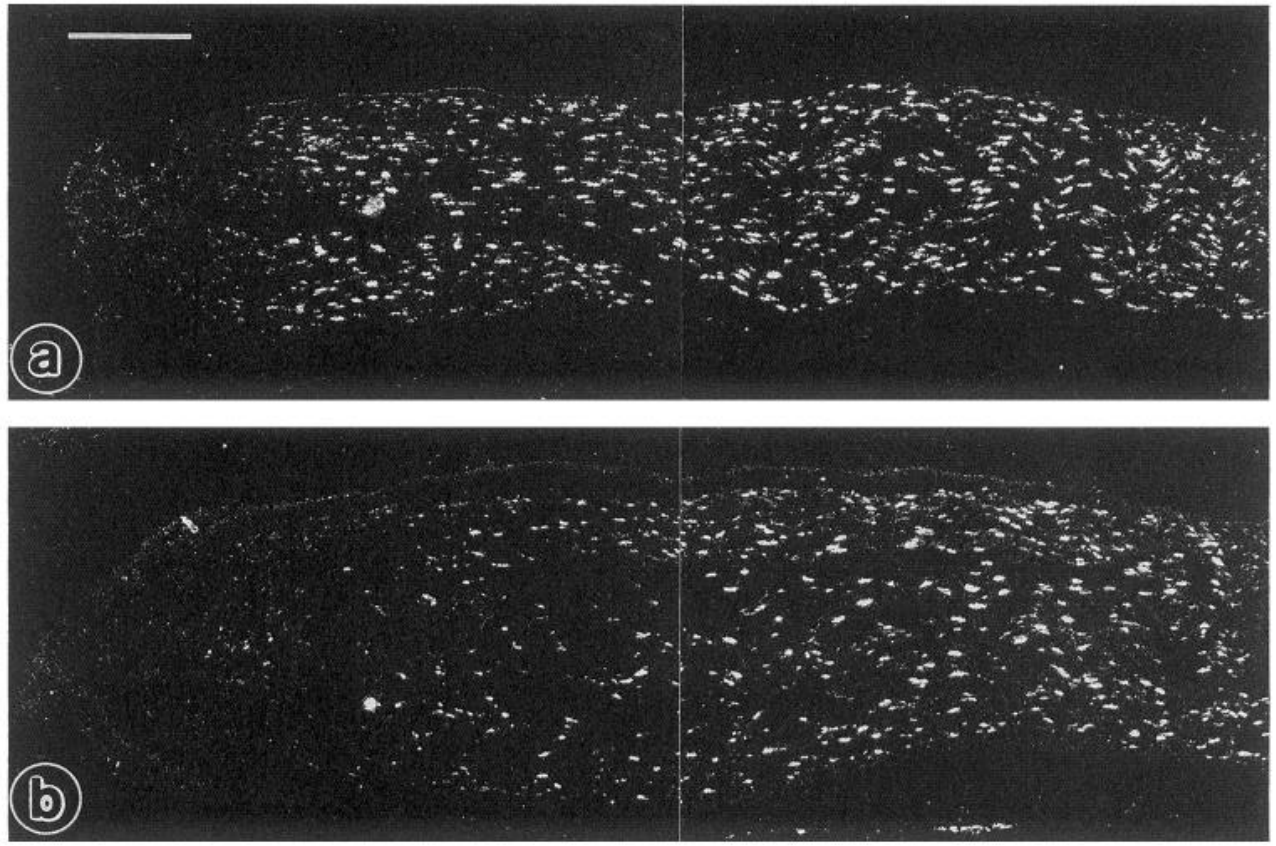

Figure 7. Expression of Po mRNA in the control and transected sciatic nerve at 3 and $36 \mathrm{hr}$ postaxotomy, as detected by in situ hybridization followed by emulsion autoradiography. Longitudinal sections of the proximal segments $3 \mathrm{hr}(a)$ and $36 \mathrm{hr}(b)$ following transection, and the distal segment at $36 \mathrm{hr}$ postaxotomy $(c)$ were hybridized to a probe specific for Po mRNA, processed for emulsion autoradiography, and visualized using dark-field illumination. The decrease in Po mRNA expression in the proximal stump $36 \mathrm{hr}$ postaxotomy $(d)$ relative to the control nerve $(e)$ is shown at higher magnification. In all panels, the transected tip of the nerve is located at the left of the photograph. Scale bar: $500 \mu \mathrm{m}$ for $a-c ; 250 \mu \mathrm{m}$ for $d$ and $e$.
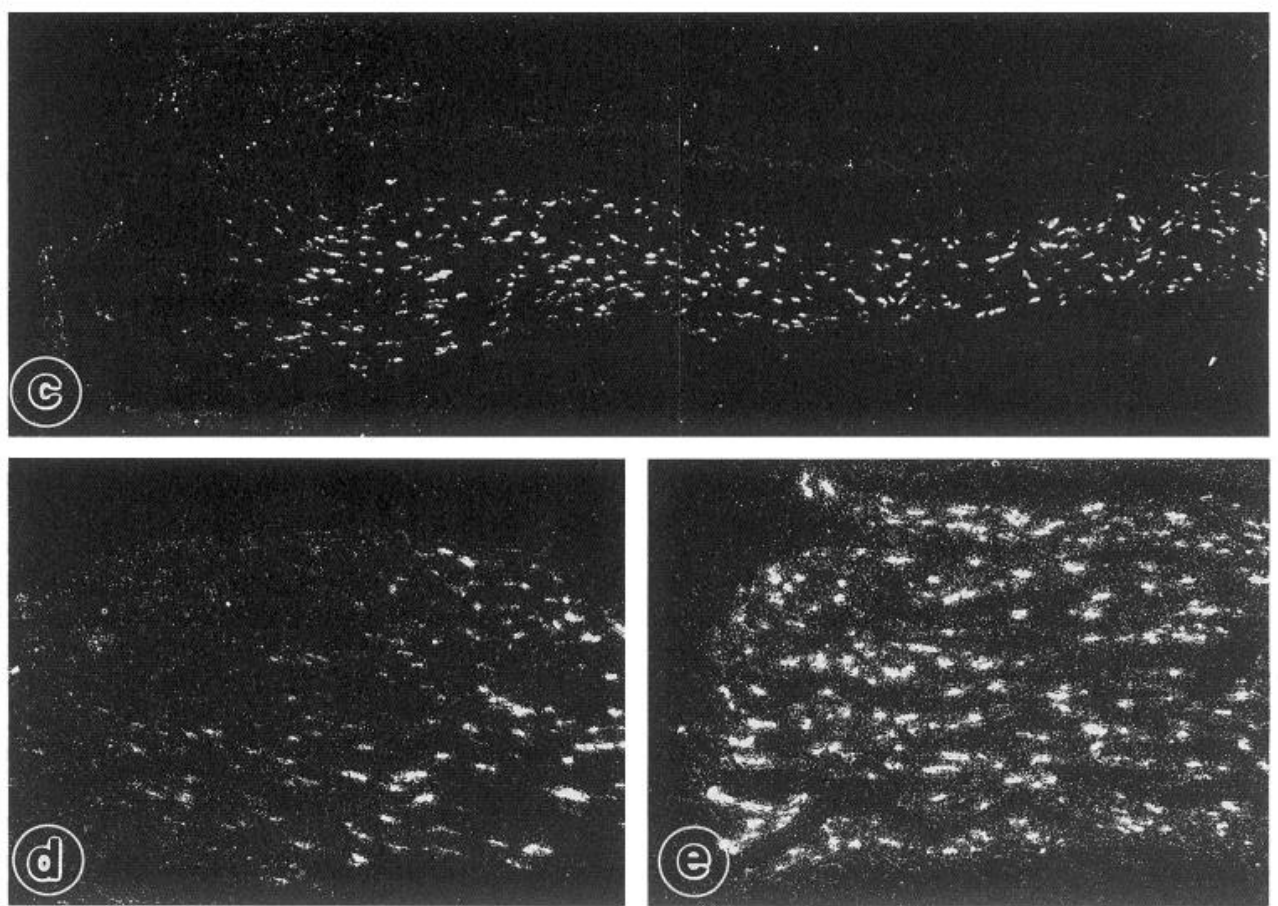

by macrophages at wound sites. TGF- $\alpha$, which binds to the EGF receptor, is also a product of wound macrophages (Rappolee et al., 1988) and increases EGF receptor protein and mRNA levels either alone or synergistically with TGF- $\beta$ or triiodothyronine (Earp et al., 1986; Kudlow et al., 1986; Fernandez-Pol et al., 1987, 1989). These increased EGF receptor mRNA levels are due both to increased transcription and to enhanced mRNA stability (Kesavan et al., 1990). Interestingly, TGF- $\alpha$ has also been shown to increase levels of its own mRNA, suggesting that a TGF- $\alpha$-regulated autocrine loop may exist (Bjorge et al., 1989).

Upregulation of EGF receptors on non-neuronal cells of the nerve following injury may be the determining factor in an increase in the capacity of these cells to respond to extracellular ligands of the EGF family. These ligands may be produced by cells within the injured nerve, or may derive from invading cells involved in the wound healing process. It is not known whether EGF or TGF- $\alpha$ is produced in the nerve, but schwannomaderived growth factor, a newly described member of the EGF family, is synthesized in sciatic nerve (Kimura et al., 1990). Furthermore, wound macrophages produce TGF- $\alpha$ and heparin-binding EGF, another new member of the EGF family (Higashiyama et al., 1991), while wound fluids contain both EGF and TGF- $\alpha$ (Rappolee et al., 1988). The latter two factors are known to be mitogenic for fibroblasts (Lembach, 1976), and can act in a noninflammatory manner to direct the wound healing process in vivo (Buckley et al., 1985; Schreiber et al., 1986). In 
addition, EGF potentiates the activity of TGF- $\beta$ (Sporn et al., 1983), a potent mitogen for purified rat Schwann cells (Ridley et al., 1989). Thus, the observed increases in EGF receptor, coupled to the synthesis of any of these members of the EGF family, may play a role both in the wound healing response, and in providing a permissive environment for axonal growth.

The spatial and temporal changes in expression of EGF receptor following nerve transection were similar to those observed for LNGF receptor. Following nerve transection, LNGF receptor mRNA (Heumann et al., 1987b) and protein (Taniuchi et al., 1986) increase dramatically in the distal segment of the injured nerve, and decrease as a function of axonal regeneration. Immunocytochemistry at the electron microscopic level indicated that this increase was localized to Schwann cells (Taniuchi et al., 1988). Our data confirm these studies and demonstrate that, at $36 \mathrm{hr}$ postaxotomy, the increase in LNGF receptor occurs in longitudinal gradients in both the proximal and distal segments, while at $72 \mathrm{hr}$ this molecule is uniformly increased in the distal segment. This localization is consistent with the hypothesis that LNGF receptor expression in Schwann cells is regulated largely as a function of Schwann cell-axon contact (Taniuchi et al., 1988).

Our results suggest that LNGF receptor increases not only in Schwann cells, but also in fibroblasts of the epineurial sheath following injury. In support of this novel localization, we demonstrate here that primary cultured fibroblasts express LNGF receptor mRNA. These results, which differ from those reported by Taniuchi et al. (1988), potentially as a consequence of the differences in localization techniques, have a number of implications. First, they suggest that the truncated form of the LNGF receptor, which is derived via posttranslational processing of the intact receptor (Barker et al., 1991), and which elevates in blood following sciatic nerve injury (DiStefano and Johnson, 1988), may be generated not only by Schwann cells, but also by fibroblasts. Fibroblasts transfected with the LNGF receptor cDNA produce both membrane-bound and truncated forms of the receptor (Barker et al., 1991). Since fibroblasts are widely distributed, it is also possible that injury of tissues other than nerve may contribute to increased circulating levels of truncated LNGF receptor. Second, LNGF receptors synthesized by fibroblasts of the epineurium are unlikely to play a role in "delivering" NGF to growing axons, as has been proposed for Schwann cells (Johnson et al., 1988), potentially indicating a paracrine role for NGF in the injured nerve (Raivich et al., 1991).

Of particular interest is the fact that the changes in EGF reccptors and NGF receptors occurred in gradients at all time points in the proximal segment, and at earlier time points in the distal segment. Our results describing the early changes in Schwann cell expression of the peripheral myelin protein Po support the concept that these spatiotemporal gradients are reflective of a more generalized nerve injury response. Po mRNA and protein have previously been shown to decrease in the distal segment of an injured nerve al time points of $2 \mathrm{~d}$ and later (Trapp et al., 1988). Our data extend these findings by demonstrating that, as early as $3 \mathrm{hr}$ posttransection, Po mRNA decreased in Schwann cells immediately adjacent to the transection site, and the decrease then progressed distally in a manner directly analogous to the increases in the two receptors we examined. All of these decreases are correlated spatially and temporally with axonal degeneration, and subsequent loss of axon-Schwann cell contact during Wallerian degeneration (PelIcgrino ct al., 1986).
Thus, the nerve injury response, which includes an upregulation of EGF receptors, involves temporal and spatial signals reflected in the cellular changes that we report here. These results suggest one of two possibilities. It is possible that the disruption of intact cytoarchitecture (i.e., appropriate Schwann cell-axon contact) is sufficient to induce the changes that occur following nerve injury. Alternatively, these gradients may be due to the fact that macrophages invade only where the cytoarchitecture is disturbed, and thereby, in a paracrine fashion, initiate the observed sequence of events (Perry et al., 1987). In that regard, both Wallerian degeneration (Xin et al., 1990) and injury-induced increases in NGF receptors (Brown et al., 1991) are reduced in macrophage-deficient mice.

We have thus described two potentially important signaling pathways in the injured peripheral nerve. The first involves autocrine/paracrine mechanisms whereby members of the EGF family bind to fibroblasts and Schwann cells that have upregulated EGF receptors, possibly as a consequence of autoregulation by members of the EGF family. The second group of proposed signaling pathways involve cell contact-mediated events, whereby loss of Schwann cell-axon contact regulates Schwann ccll gene expression, and potentially allows these cells to reenter the cell cycle and/or respond to some of the EGF ligands.

\section{References}

Acheson A, Barker PA, Alderson RF, Miller FD, Murphy RA (1991) Detection of brain-derived neurotrophic factor-like activity in fibroblasts and Schwann cells: inhibition by antibodies to NGF. Neuron $7: 265-275$.

Adelmann-Grill BC, Wach F, Cully Z, Hein R, Krieg T (1990) Chemolactic migration of normal dermal fibroblasts towards epidermal growth factor and its modulation by platelet-derived growth factor and transforming growth factor-beta. Eur J Cell Biol 51:322-326.

Allt $G$ (1976) Pathology of the peripheral nerve. In: The peripheral nerve (Landon DN, ed), pp 666-739. New York: Wiley.

Anderson PN, Turmaine M (1986) Peripheral nerve regeneration through grafts of living and freeze-dried CNS tissue. Neuropathol Appl Neurobiol 12:389-399.

Anderson PN, Wondham P, Turmaine M (1989) Peripheral nerve regeneration through optic nerve grafts. Acta Neuropathol (Berl) 77: 525-534.

Assoian RK, Frolik CA, Roberts AB, Miller DM, Sporn MB (1984) Transforming growth factor $\beta$ controls receptor levels for epidermal growth factor in NRK fibroblasts. Cell 36:35-41.

Baichwal RR, Bigbee JW, DeVries GH (1988) Macrophage-mediated myelin-related mitogenic factor for cultured Schwann cells. Proc Natl Acad Sci USA 85:1701-1705.

Barker PA (1991) Characterization of NGF receptor gene products in Schwann cells and fibroblasts. PhD thesis, University of Alberta, Canada.

Barker PA, Miller FD, Large TH, Murphy RA (1991) Generation of the truncated NGF receptor by rat Schwann cells: evidence for posttranslational processing. J Biol Chem 266:19113-19119.

Benfey M, Aguayo AJ (1982) Extensive elongation of axons from rat brain into peripheral nerve grafts. Nature 296:150-152.

Bcuche W, Fricde RL (1984) The role of non-resident cells in Wallerian degeneration. J Neurocytol 13:767-796.

Bjorge JD, Paterson AJ, Kudlow JE (1989) Phorbol ester or epidermal growth factor (EGF) stimulates the concurrent accumulation of mRNA for the EGF receptor and its ligand transforming growth factor- $\alpha$ in a breast cancer cell line. J Biol Chem 264:4021-4027.

Bowen-Pope DF, Dicorleto PE, Ross R (1983) Interactions between the receptors for platelet-derived growth factor and epidermal growth factor. J Cell Biol 96:679-683.

Brockes JP, Field KL, Raff MC (1979) Studies on cultured rat Schwann cells. I. Establishment of purified populations from cultures of peripheral nerve. Brain Res 165:105-118.

Brown MC, Perry VH, Lunn ER, Gordon S, Heumann R (1991) Macrophage dependence of peripheral sensory nerve regeneration: possible involvement of nerve growth factor. Ncuron 6:359-370. 
Brunden KR, Windebank AJ, Poduslo JF (1990) Rolc of axons in the regulation of Po biosynthesis by Schwann cells. J Neurosci Res 26: 135-143.

Buckley A, Davidson JM, Kamerath CD, Wolt TB, Woodward SC (1985) Sustained release of epidermal growth factor accelerates wound repair. Proc Natl Acad Sci USA 82:7340-7344.

Carbonetto S, Evans D, Cochard P (1987) Nerve fiber growth in culture on tissue substrata from central and peripheral nervous systems. $J$ Neurosci 7:610-620.

Carpenter $G$ (1987) Receptors for epidermal growth factor and other polypeptide mitogens. Annu Rev Biochem 56:881-914.

Chandler CE, Parsons LM, Hosang M, Shooter EM (1984) A monoclonal antibody modulates the interaction of nerve growth factor with PC1 2 cells. J Biol Chem 259:6882-6889.

Collins MKL, Sinnett-Smith JW, Rozengurt E (1983) Platelet-derived growth factor treatment decreases the affinity of the epidermal growth factor receptors of Swiss 3T3 cells. J Biol Chem 258:11689-11693.

David S, Aguayo AJ (1981) Axonal elongation into peripheral nervous system "bridges" after central nervous system injury in adult rats. Science 214:931-933.

DiStefano PS, Johnson EM Jr (1988) Identification of a truncated form of the nerve growth factor receptor. Proc Natl Acad Sci USA 85:270-274.

Downward J, Yarden Y, Mayes E, Scrace G, Totty N, Stockwell P, Ullrich A, Schlessinger J, Waterfield MD (1984) Close similarity of epidermal growth factor receptor and V-erb-B oncogene protein sequences. Nature 307:521-527.

Earp HS, Austin KS, Blaisdell J, Rubin RA, Nelson KG, Lee LW, Grisham JW (1986) Epidermal growth factor (EGF) stimulates EGF receptor synthesis. J Biol Chem 261:4777-4780.

Fernandez-Pol JA, Klos DJ, Hamilton PD, Talkad VD (1987) Modulation of epidermal growth factor receptor gene expression by transforming growth factor- $\beta$ in a human breast carcinoma cell line. Cancer Res 47:4260-4265.

Fernandez-Pol JA, Klos DJ, Hamilton PD (1989) Modulation of transforming growth factor alpha-dependent expression of epidermal growth factor receptor gene by transforming growth factor beta, triindothyronin, and retinoic acid. J Cell Biochem 41:159-170.

Finesmith TH, Broadley KN, Davidson JM (1990) Fibroblasts from wounds of different stages of repair vary in their ability to contract a collagen gel in response to growth factors. J Cell Physiol 144:99-107.

Goodman RH, Aron DC, Roos BA (1983) Rat pre-prosomatostatin: structure and processing by microsomal membranes. J Biol Chem 258:5570-5573.

Gospodarowicz D (1975) Purification of a fibroblast growth factor from bovine pituitary. J Biol Chem 250:2515-2520.

Gupta SK, Poduslo JF, Mezei C (1988) Temporal changes in Po and MBP gene expression after crush-injury of the adult peripheral nerve. Mol Brain Res 4:133-141.

Guth L (1956) Regeneration in the mammalian peripheral nervous system. Physiol Rev 36:441-478.

Guth L, (1975) History of central nervous system regeneration research. Exp Neurol 48:3-15.

IIaigler H, Ash JF, Singer SJ, Cohen S (1978) Visualization by fluorescence of the binding and internalization of epidermal growth factor in human carcinoma cells A-431. Proc Natl Acad Sci USA 75:33173321 .

Heumann R, Korsching S, Bandtlow C, Thoenen H (1987a) Changes of nerve growth factor synthesis in nonneuronal cells in response to sciatic nerve transection. J Cell Biol 104:1623-1631.

Heumann R, Lindholm D, Bandtlow C, Meyer M, Radeke MJ, Misko TP, Shooter E, Thoenen H (1987b) Differential regulation of mRNA encoding nerve growth factor and its receptor in rat sciatic nerve during development, degeneration, and regeneration: role of macrophages. Proc Natl Acad Sci USA 84:8735-8739.

Higashiyama S, Abraham JA, Miller J, Fiddes JC, Klagsbrun M (1991) A heparin-binding growth factor secreted by macrophage-like cells that is related to EGF. Science 251:936-939.

Huff KR, Schreier W, Ibric L (1990) Proliferation-related responses in rat astrocytes to epidermal growth factor. Int J Dev Neurosci 8: 255-266.

Johnson EM Jr, Taniuchi M, DiStefano PS (1988) Expression and possible function of nerve growth factor receptors on Schwann cells. Trends Neurosci 11:299-304.

Kesavan P, Das P, Kern J, Das M (1990) Regulation of stability and synthesis of EGF-rcceptor mRNAs encoding for intact and truncated receptor forms. Oncogene 5:483-488.

Kimura H, Fischer WH, Schubert D (1990) Structure, expression and function of a schwannoma-derived growth factor. Nature 348:257260.

Kligman D, Hilt DC (1988) The $\mathbf{S 1 0 0}$ protein family. Trends Biochem Sci 13:437-443.

Kudlow JE, Cheung C-YM, Bjorge JD (1986) Epidermal growth factor stimulates the synthesis of its own receptor in a human breast cancer cell line. J Biol Chem 261:4134-4138.

Lai C, Lemke G (1991) An extended family of protein-tyrosine kinase genes differentially expressed in the vertebrate nervous system. Neuron 6:691-704.

LeBlanc AC, Poduslo JF (1990) Axonal modulation of myelin gene expression in the peripheral nerve. J Neurosci Res 26:317-326.

Lembach KJ (1976) Induction of human fibroblast proliferation by epidermal growth factor (EGF): enhancement by an EGF-binding arginine esterase and by ascorbate. Proc Natl Acad Sci USA 73:183187.

Lemke G, Axel R (1985) Isolation and sequence of a cDNA encoding the major structural protein of peripheral myelin. Cell 40:501-508.

Leutz A, Schachner M (1981) Epidermal growth factor stimulates DNA-synthesis of astrocytes in primary cerebellar cultures. Cell Tissue Res 220:393-404.

Lewis EJ, Tank AW, Weiner N, Chikaraishi DM (1983) Regulation of tyrosine hydroxylase mRNA by glucocorticoid and cyclic AMP in a rat pheochromocytoma cell line. J Biol Chem 258:14632-14637.

Lindholm D, Heumann R, Hengerer B, Thoenen H (1988) Interleukin 1 increases stability and transcription of mRNA encoding nerve growth factor in cultured rat fibroblasts. J Biol Chem 263:16348-16351.

Massague J (1985) Transforming growth factor- $\beta$ modulates the highaffinity receptors for epidermal growth factor and transforming growth factor- $\alpha$. J Cell Biol 100:1508-1514.

Miller FD, Tetzlaff W, Bisby MA, Fawcett JW, Milner RJ (1989a) Rapid induction of the major embryonic $\alpha$-tubulin mRNA, T $\alpha 1$, during nerve regeneration in adult rats. $J$ Neurosci 9:1452-1463.

Miller FD, Orimek G, Milner RJ, Bloom FE (1989b) Regulation of neuronal oxytocin mRNA by ovarian steroids in the mature and developing hypothalamus. Proc Natl Acad Sci USA 86:2468-2472.

Miller FD, Mathew TC, Toma JG (1991) Regulation of nerve growth factor receptor gene expression by nerve growth factor in the developing peripheral nervous system. J Cell Biol 112:303-312.

Naus CCG, Miller FD, Morisun JH, Bloom FE (1988) Immunohistochemical and in situ hybridization analysis of the development of the rat somatostatin-containing neocortical neuronal system. J Comp Neurol 269:448-463.

Osborn M, Weber K (1982) Immunofluorescence and immunocytochemical procedures with affinity purified antibodies: tubulin-containing structures. Methods Cell Biol 24:97-132.

Pellegrino RG, Politis MJ, Ritchie JM, Spencer PS (1986) Events in degenerating cat peripheral nerve: induction of Schwann cell $S$ phase and its relation to nerve fiber degeneration. J Neurocytol 15:17-28.

Perry VH, Brown MC, Gordon S (1987) The macrophage response to central and peripheral nerve injury. A possible role for macrophages in regeneration. J Exp Med 165:1218-1223.

Politis MJ, Ederle K, Spencer PS (1982) Tropism in nerve regeneration in vivo. Attraction of regenerating axons by diffusible factors derived from cells in distal nerve stumps of transected peripheral nerves. Brain Res 253:1-12.

Radeke MJ, Misko TP, Hsu C, Herzenberg LA, Shooter EM (1987) Gene transfer and molecular cloning of the rat nerve growth factor receptor. Nature 325:593-597.

Raivich G, Kreutzberg GW (1987) Expression of growth factor receptors in injured nervous tissue. I. Axotomy leads to a shift in the cellular distribution of specific $\beta$-nerve growth factor binding in the injured and regenerating PNS. J Neurocytol 16:689-700.

Raivich G, Hellweg R, Kreutzberg GW (1991) NGF receptor-mediated reduction in axonal NGF uptake and retrograde transport following sciatic nerve injury and during regeneration. Neuron 7:151164.

Ramon y Cajal S (1928) Degeneration of the peripheral stump. In: Degeneration and regeneration of the nervous system, Vol 1 (May RM, ed and transl), pp 100-126. Oxford: Oxford UP.

Rappolee DA, Mark D, Banda MJ, Werb Z (1988) Wound macro- 
phages express TGF- $\alpha$ and other growth factors in vivo: analysis by mRNA phenotyping. Science 241:708-712.

Richardson PM, McGuinness UM, Aguayo AJ (1980) Axons from CNS neurones regenerate into PNS grafts. Nature 284:264-265.

Ridley AJ, Davis JB, Stroobant P, Land H (1989) Transforming growth factors- $\beta 1$ and $\beta 2$ are mitogens for rat Schwann cells. J Cell Biol 109: 3419-3424.

Savio T, Schwab ME (1989) Rat CNS white matter, but not gray matter, is nonpermissive for neuronal cell adhesion and fiber outgrowth. J Neurosci 9:1126-1133.

Scaraville F (1984) The influence of distal environment on peripheral nerve regeneration across a gap. J Neurocytol 13:1027-1041.

Schreiber AB, Winkler ME, Derynck R (1986) Transforming growth factor- $\alpha$ : a more potent angiogenic mediator than epidermal growth factor. Science 232:1250-1253.

Schwab ME, Thoenen $H$ (1985) Dissociated neurons regenerate into sciatic but not optic nerve explants in culture irrespective of neurotrophic factors. J Neurosci 5:2415-2423.

Sporn MB, Roberts AB, Shull JH, Smith JM, Ward JM (1983) Polypeptide transforming growth factors isolated from bovine sources and used for wound healing in vivo. Science 219:1329-1331.

Stoll G, Griffin JW, Li CY, Trapp BD (1989) Wallerian degeneration in the peripheral nervous system: participation of both Schwann cells and macrophages in myelin degradation. J Neurocytol 18:671-683.

Taniuchi M, Clark HB, Johnson EM Jr (1986) Induction of nerve growth factor receptor in Schwann cells after axotomy. Proc Natl Acad Sci USA 83:4094-4098.

Taniuchi M, Clark HB, Schweitzer JB, Johnson EM Jr (1988) Expression of nerve growth factor receptors by Schwann cells of axotomized peripheral nerves: ultrastructural location, suppression by axonal contact, and binding properties. J Neurosci 8:664-681.

Trapp BD, Hauer P, Lemke G (1988) Axonal regulation of myelin protein mRNA levels in actively myelinating Schwann cells. J Neurosci 8:3515-3521.

Ullrich A, Schlessinger J (1990) Signal transduction by receptors with tyrosine kinase activity. Cell 61:203-212.

Ullrich A, Coussens L, Hayflick JS, Dull RJ, Gray A, Tam AW, Lee J, Yarden Y, Libermann TA, Schlessinger J, Downward J, Mayes ELV, Whittle N, Waterfield MD, Seeburg PH (1984) Human epidermal growth factor receptor cDNA sequence and aberrant expression of the amplified gene in A431 epidermoid carcinoma cells. Nature 309: 418-425.

Veraa RP, Grafstein B (1981) Cellular mechanisms for recovery from nervous system injury: a conference report. Exp Neurol 71:6-75.

Williams LR, Powell HC, Lundborg G, Varon S (1984) Competence of nerve tissue as distal insert promoting nerve regeneration in a silicone chamber. Brain Res 293:201-211.

Xin L, Richardson PM, Gervais F, Skamene E (1990) A deficiency of axonal regeneration in C57BL/6J mice. Brain Res 510:144-146. 